\title{
Global imaging will widen epidemiologic knowledge of appendicitis by perceiving the dilated crypts in archival collections worldwide
}

\author{
Wilson IB Onuigbo \\ Department of Pathology, Medical Foundation and Clinic, 8 Nsukka Lane, Enugu 400001, Nigeria
}

\begin{abstract}
Appendicitis is a worldwide problem with a fascinating epidemiology which deserves researches. In the 1960s, such much needed research was directed to expanding its boundaries. This resulted in promoting its acute "limited" variety. It was in this context that the crypt abscess within it came into prominence. Accordingly, what can follow when these abscesses resolve? It is necessarily the formation of determinable ovoid spaces. Since these can be recognized with biomedical graphics, it is hypothesized that archival films, which abound all over the world, will promote the epidemiologic study of this vestigial organ.
\end{abstract}

\section{Hypothesis}

Worldwide problems concern the epidemiology of appendicitis undoubtedly $[1,2]$. In order to improve on a better knowledge of it, Howie [3] stressed the importance of including the "limited" form of it in classifications! However, as he put it, "I have disregarded solitary crypt abscesses which do not show invasion of the adjacent stroma by polymorphonuclear leucocytes."

I am persuaded that such abscesses found in the crypts of Lieberkuhn are an important phenomenon, especially as their pictures must vary from (a) that of emptiness, (b) through scanty necrotic polymorphs, and (c) to crowding with lively polymorphs. Figure 1 illustrates the classic ovoid space which is the seemingly empty dilated crypt.

My impression is that this picture came to my mind because of examining the specimens from the patients of the Igbo ethnic group [4], in whom the appendix mass was treated and allowed to resolve before the resort to surgery [5]. Moreover, since incidental appendicectomy cases are likely to reveal hidden pathologies $[6,7]$, they are liable to be positively identifiable when involved. In all probability, the more the collections which are made, the more the positive knowledge that will accrue [8]. And this is where archival radiographs can be mustered strong worldwide.

\section{References}

1. Han H, Kim H, Rehman A, Jang SM, Paik SS (2014) Appendiceal Crohn's disease clinically presenting as acute appendicitis. World J Clin Cases 2: 888-892. [Crossref]

2. Campbell LK, Havens JM, Scott MA Lamps LW (2006) Molecular detection of campylobacter jejuni in archival cases of acute appendicitis. Modern Pathol 19: 10421046. [Crossref]

Copyright: $\left(\mathrm{C}_{2017}\right.$ Onuigbo WIB. This is an open-access article distributed under the terms of the Creative Commons Attribution License, which permits unrestricted use, distribution, and reproduction in any medium, provided the original author and source are credited.

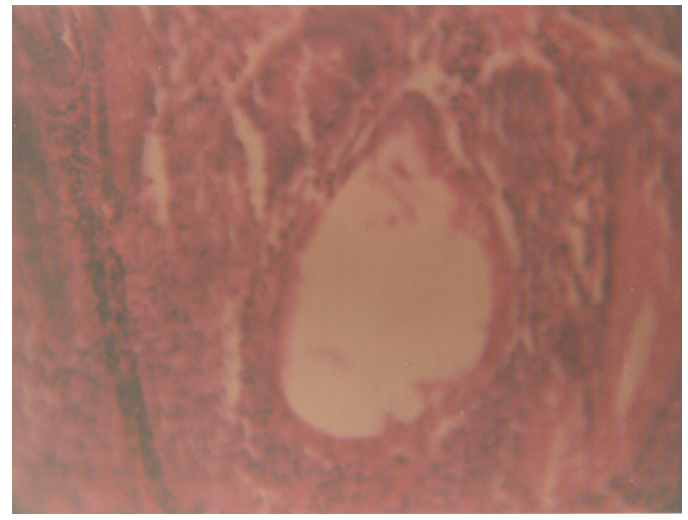

Figure 1. Microphotograph showing centrally situated empty ovoid distended Lieberkuhn gland.

3. Howie JG (1964) Too few appendicectomies? Lancet 1: 1240-1242. [Crossref]

4. Basden GT. Niger Ibos. Cass, London 1966.

5. Onuigbo WI (1977) Resolution of the appendiceal mass in Nigerian Igbos. Dis Colon Rectum 20: 679-680. [Crossref]

6. Onuigbo WIB (2016) Epidemiologic perspectives of incidental appendectomy during ovariectomy for teratoma in a developing community, Nigeria. J Pharm Res 1: 1-2.

7. Wie HJ1, Lee JH, Kyung MS, Jung US, Choi JS (2008) Is incidental appendectomy necessary in women with ovarian endometrioma? Aust NZJ Obstet Gynaecol 48: 107-111. [Crossref]

8. Salom EM, Schey D, Peñalver M, Gómez-Marín O, Lambrou N, et al. (2003) The safety of incidental appendectomy at the time of abdominal hysterectomy. Am J Obstet Gynecol 189: 1563-1567. [Crossref]

Correspondence to: Wilson IB Onuigbo, Department of Pathology, Medical Foundation and Clinic, 8 Nsukka Lane, Enugu 400001, Nigeria, E-mail: wilson. onuigbo@gmail.com

Key words: appendicitis, crypt, abscess, dilated space, archival films, global imaging, epidemiology

Received: November 02, 2017; Accepted: November 13, 2017; Published: November 16, 2017 